\title{
Heavy Metals Bioaccumulation in Edible Marine Bivalve Mollusks of Tudor Creek Mombasa Kenya
}

\author{
Mariam M. Swaleh ${ }^{1}$, RenisonRuwa ${ }^{2}$, Moses N. Wainaina ${ }^{1}$, Loice M. Ojwang, ${ }^{1 *}$, \\ Samuel L. Shikuku and Justin K. Maghanga ${ }^{3}$ \\ ${ }^{l}$ Department of Chemistry, Pwani University P.O Box 195-80108 Kilifi, Kenya. \\ ${ }^{2}$ Kenya Marine and Fisheries Research Institute (KMFRI) P.O Box 81651080100 Mombasa, Kenya. \\ ${ }^{3}$ Department of Mathematics and informatics, TaitaTaveta University College P.O Box 635-80300 Voi, Kenya.
}

\begin{abstract}
The bioaccumulation of heavy metals and their distribution were investigated in selected marine bivalve mollusks of genus (saccostreacucullata) oysters, (Mytilus edulis) mussels and donax at Tudor creek in Mombasa Kenya. An atomic absorption spectrometer was used in this study to determine the concentration levels of heavy metals in the organisms' flesh and shell, water, sediment and rock samples.

Heavy metals concentration level among the bivalve mollusks was as follows: mussels: $\mathrm{Zn}>\mathrm{Fe}>\mathrm{Cr}>\mathrm{Pb}>$ $\mathrm{Cu}>\mathrm{Mn}>\mathrm{Cd}$, oysters: $\mathrm{Zn}>\mathrm{Fe}>\mathrm{Cu}>\mathrm{Pb}>\mathrm{Mn}>\mathrm{Cr}>\mathrm{Cd}$ and donax: $\mathrm{Zn}>\mathrm{Fe}>\mathrm{Cu}>\mathrm{Pb}>\mathrm{Cr}>\mathrm{Mn}>\mathrm{Cd}$. Heavy metals varied with location, genus, size, tissue and shells of the mollusks. The results showed that of all the metals analyzed $\mathrm{Fe}$ and $\mathrm{Zn}$ were the most abundant. $\mathrm{Pb}$ and $\mathrm{Cd}$ were detected in the shell samples but occurred in levels below the detection limit in the flesh samples of all bivalves except oyster samples.

Mussels had the highest concentration of Zn overall. The results suggested that mussels are good accumulators of $\mathrm{Zn}$ whereas oysters accumulate $\mathrm{Cd}$ and donax were poor accumulators of all metals except $\mathrm{Cd}$ in shell samples. The shells had high concentration of the toxic heavy metals $\mathrm{Cd}$ and Pb while the flesh had high concentration of the essential metals like $\mathrm{Cu}, \mathrm{Zn}$ and $\mathrm{Fe}$. The bivalves had a high concentration of the heavy metals therefore, could pose a health risk to humans if consumed. It was concluded that bioaccumulation of heavy metals varied with location, species type, body part and size of bivalve. It was further concluded that the marine bivalve were better accumulators of heavy metals than water, sediment and rocks samples.
\end{abstract}

Keywords: edible, bivalves, heavy metals, bioaccumulation, Tudor creek

\section{Introduction}

Bioaccumulation can be defined as the progressive increase of a toxic chemical in tissues of living organisms because the organism can uptake high quantities of the toxic chemicals compared to its ability to remove it [1], [2]. Heavy metals have a density above $5 \mathrm{~g} / \mathrm{cm}^{3}$ [3]. They are non-biodegradable and can therefore; bioaccumulate in an environment after prolonged exposure. They are hazardous pollutants that pose a danger to the marine organisms as well as the degradation of the marine ecosystem[4]. Therefore, monitoring of heavy metals in the marine environment is a very important practice.

Marine organism can be exposed to heavy metals through uptake of water, ingestion of sediment particles and via food chains [5], [6]. Marine mollusks have a tendency to bioaccumulate heavy metals at higher concentration more than the sediment or water in their environment. Bivalves are filter feeders and feed through their gills [5], [6]. Theyplay an important role in aquatic food chains because they represent the primary consumers in the ecosystem [7].

The Kenyan coast generates a lot of income for Kenya through fisheries and tourism activities. However, the marine environment has undergone a lot of stress due to urbanization and high population growth in the coastal towns. This has led to pollution of the environment which pose a danger to both the marine organisms and humans along the coastline [8], [9].

Mombasa is the largest coastal town in Kenya; it is home to over 1.2 million people [10]. Pollution of the marine environment has been a problem for a long time. Major sources of pollution are solid waste, municipal waste water and industrial waste that is deposited along the shores into the ocean. This practice has led to destruction of the mangrove ecosystem as well as human health problems [11], [9], [8].

Heavy metals pollution at Tudor Creek in Mombasa has been a major concern as high levels of heavy metals have been reported by several researchers [12], [13], [14], [15]. Therefore, this study aimed at assessing bioaccumulation of heavy metals in marine bivalve mollusks from Tudor creek Mombasa Kenya. This was done to identify a good biomonitoring organism as well as determine the level of heavy metals pollution at Tudor creek. This study focused on three edible bivalve from the Kenyan coast namely (saccostreacucullata) oysters, (Mytilus edulis) mussels and donax (Fig1). 

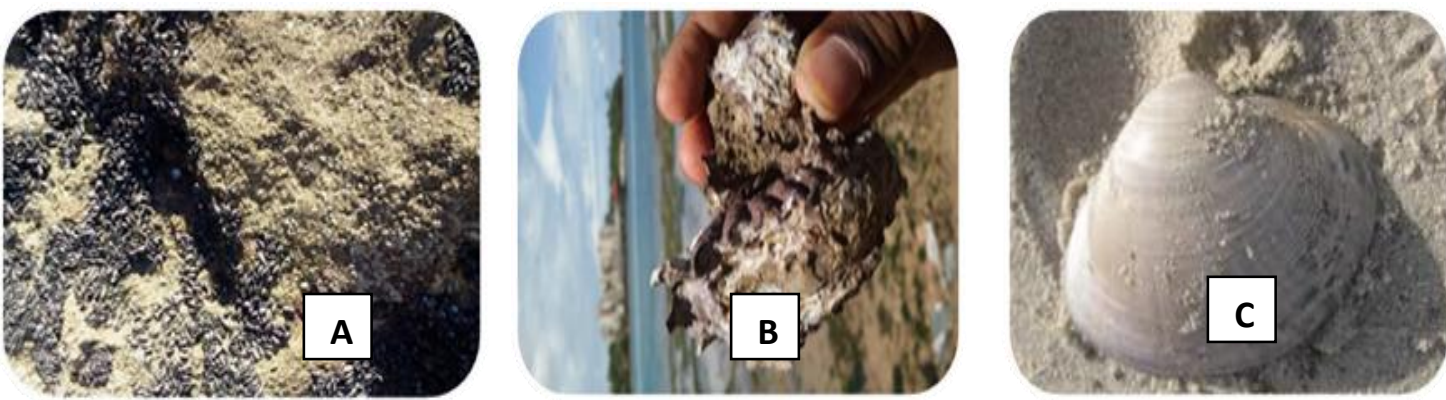

Figure 1: a) Mussels (Mytilus edulis ${ }^{3}$ ), b) Oysters (Saccostrea cucullata ${ }^{2}$ ), c) Donax. Sources: 2: [16], [17]

Bivalves like Donax, Mussels and Oysters, have been used as biomonitors of heavy metals globally. This is because they can accumulate some metals at levels high above those in their abiotic environment. They can bioconcentrate chemicals by factors of $10^{2}$ to $10^{5}$ from sea water thus making the detection easier [18]. Therefore, it is easier to estimate the biologically available heavy metals than using water or sediments [19], [20]. The uptake, bioaccumulation and concentration of metals in bivalves depends on several factors which include; species (by sex, size and age), physical chemical changes, different sites on body surface, seasons, location and habitat [19], [21], [20].

The bivalve shells can provide information of heavy metals pollution of the environment in their microhabitats over a period of time. This is because they reflect on the environmental history of the heavy metals in the environment [22], [23], [24]. Shells of sea animals are made mainly of two minerals of calcium carbonate which are calcite and aragonite [25]. The nacre part of the shell has been observed to be a site of biologically deposited heavy metals. The bivalve shells are thus said to be better indicators of pollution [22].

Finally, bivalves are sea foods that are of commercial value worldwide. Therefore, measurement of chemical contamination is of important interest particularly as a public health concern [18], [21], [26].

\subsection{Study Area Description}

\section{Materials And Methods}

Tudor creek bounds Mombasa Island on the north west and is located in equatorial zone between $39^{\circ}$ $30^{\prime} \mathrm{E}$ and $39^{\circ} 45^{\prime} \mathrm{E}$ longitude and $3^{\circ} 4.5^{\prime} \mathrm{S}$ and $4^{\circ} 15^{\prime}$ 'Slatitude, as shown in fig 2[27], [28].

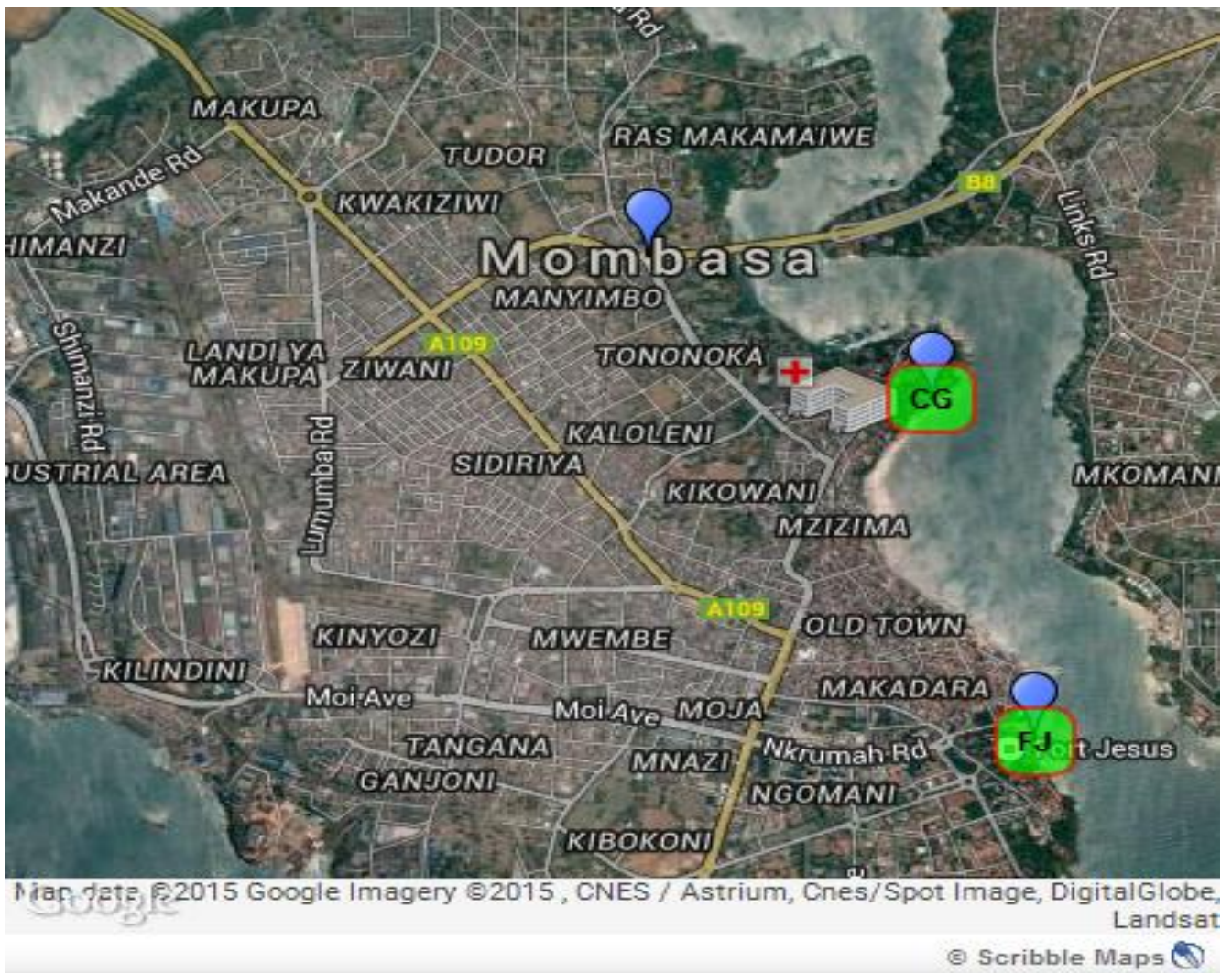

Figure 2: Image of Mombasa showing sampling sites FJ (Fort Jesus) and CG (Coast General Hospital) 
The sampling sites, as shown in fig 1, were Fort Jesus (FJ) South 04 03'53.6”, East 039 40' 17.9” and Coast General Hospital (CG) South $04^{\circ} 3^{\prime}$ '53.8', East 039 40' 17.9”. These sites were chosen because of the anthropogenic activities that occur around these stations. Fort Jesus area is a rocky shore while Coast General Hospital is a sandy shore. Fort Jesus is a tourist's attraction site; the area hosts a museum and also used for water sports events, while Coast General Hospital sampling site is near a hospital and used for fishing and swimming. The two sites chosen for this study have municipal waste disposal points at the seashore.

\subsection{Sample Collection, Preparation and Analysis}

The samples were collected at Tudor creek. Donax were samples from a sandy shore at Coast General Hospital while oysters and mussels were sampled from a rocky shore at Fort Jesus.

Oysters were sampled using a chisel while mussels and donax were handpicked during low tide. The mollusks were classified into three groups of ten organisms each based on their sizes and weight small, medium and large (Table 1).

Table 1: Classification of bivalves into size

\begin{tabular}{|l|l|l|l|l|}
\hline Size & Oyster & Mussels & Donax \\
\hline Length (mm) & Small & $26.04 \pm 1.88$ & $11.33 \pm 1.32$ & $13.66 \pm 1.71$ \\
\cline { 2 - 5 } & Medium & $35.65 \pm 4.70$ & $16.32 \pm 1.81$ & $17.56 \pm 0.52$ \\
\cline { 2 - 5 } & Large & $62.70 \pm 8.56$ & $20.44 \pm 0.67$ & $21.07 \pm 1.29$ \\
\hline \multirow{3}{*}{ Width (mm) } & Small & $17.60 \pm 1.78$ & $6.91 \pm 0.77$ & $10.56 \pm 0.98$ \\
\cline { 2 - 5 } & Medium & $35.65 \pm 4.70$ & $9.97 \pm 1.22$ & $13.40 \pm 0.70$ \\
\cline { 2 - 5 } & Large & $38.86 \pm 7.21$ & $10.07 \pm 1.07$ & $15.26 \pm 1.06$ \\
\hline Weight (g) & Small & $3.24 \pm 0.73$ & $0.59 \pm 0.14$ & $1.00 \pm 0.26$ \\
\cline { 2 - 5 } & Medium & $40.10 \pm 16.79$ & $1.22 \pm 0.23$ & $1.88 \pm 0.35$ \\
\cline { 2 - 5 } & Large & $61.03 \pm 20.79$ & $1.53 \pm 0.18$ & $2.93 \pm 0.79$ \\
\hline
\end{tabular}

The samples were washed in a tap of water using a plastic brush to remove any dirt attached to the shell surface. The shells and flesh of each bivalve were separated, dried in the oven at $60^{\circ} \mathrm{C}$ for 2 days [26], then ground using a mortar and pestle and stored in the dessicator. Digestion of the flesh samples was done according topublished methods[19], while shells were digested according to the United States Environmental Protection Agency (USEPA) method 3050A.

Water samples were put in $100 \mathrm{~mL}$ bottles and acidified on the spot. The rock samples were sampled using a hammer and chisel while the surface sediment were scooped using a shovel. The samples were stored in plastic Ziploc bags then stored in ice for transportation. The rock samples were sampled depending on their levels at the shore between the upper and lower eulittoral zone at the shore. Once in the laboratory, the samples were cleaned, dried at $60^{\circ} \mathrm{C}$ then ground using a motar and pestle.

Digestion of rock and sediment samples was done according to the United States Environmental Protection Agency (USEPA) method 3050A. Water samples were digested according to USEPA method $3005 \mathrm{~B}$. Analysis was done by GF - 990 Shimadzu flame atomic absorption spectrometer.

Table 2: AAS instrument parameters

\begin{tabular}{|l|l|l|l|l|l|l|l|}
\hline Parameters & Pb & Cd & Cu & Mn & Fe & Zn & Cr \\
\hline Wavelength(nm) & 217 & 228.8 & 324.7 & 279.5 & 248.3 & 213.9 & 357.9 \\
\hline Slit width(nm) & 0.4 & 0.4 & 0.4 & 0.4 & 0.2 & 0.4 & 0.4 \\
\hline Lamp current(mA) & 5 & 5 & 5 & 5 & 5 & 5 & 5 \\
\hline Detection limit(mg/l) & 0.012 & 0.0028 & 0.004 & 0.002 & 0.0046 & 0.003 & 0.05 \\
\hline Flame & Air/ acetylene \\
\hline Flame Temperature & $2300^{\circ} \mathrm{C}$ \\
\hline
\end{tabular}

\section{Results And Discussion}

\subsection{Concentration Levels of Heavy Metals in Bivalves}

The concentration levels of heavy metals varied from species to species and size of the bivalves (Fig 3 ). The range of heavy metals concentration in all the species was as follows: Fe: $9.31 \pm 3.06 \mu \mathrm{g} / \mathrm{g}$ to $380.59 \pm 101.31 \mu \mathrm{g} / \mathrm{g}, \mathrm{Zn}: \mathrm{Nd}$ to $2504.92 \pm 6.96 \mu \mathrm{g} / \mathrm{g}, \mathrm{Cu}: 2.90 \pm 0.48 \mu \mathrm{g} / \mathrm{g}$ to $254.98 \pm 9.50 \mu \mathrm{g} / \mathrm{g}, \mathrm{Mn}: \mathrm{Nd}$ to $19.31 \pm 1.71 \mu \mathrm{g} / \mathrm{g}, \mathrm{Pb}$ : $\mathrm{Nd}$ to $70.35 \pm 2.47 \mu \mathrm{g} / \mathrm{g}, \mathrm{Cd}: \mathrm{Nd}$ to $7.15 \pm 1.14 \mu \mathrm{g} / \mathrm{g}$ and $\mathrm{Cr}$ : $\mathrm{Nd}$ to $98.24 \pm 19.73 \mu \mathrm{g} / \mathrm{g}$.

$\mathrm{Fe}$ and $\mathrm{Zn}$ were the most abundant heavy metals in all the molluscs (Fig $3 \mathrm{~d}$ and $\mathrm{f}$ ) while $\mathrm{Mn}$ and $\mathrm{Cr}$ concentration levels for most of the organisms were very low (Fig 3 a and c). Donax had the lowest concentration of Fe (Fig 3 d) while oysters and mussels had the highest concentration levels of Zn (Fig 3f). 


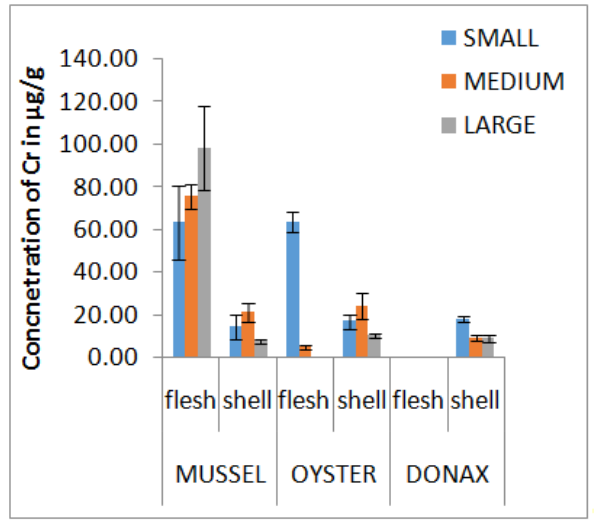

a.

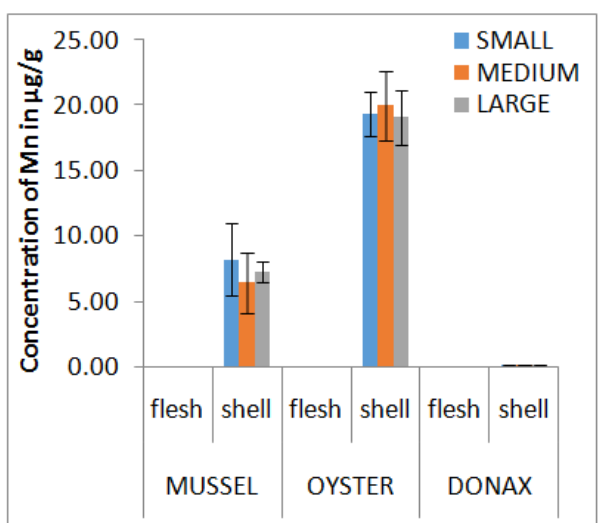

c.

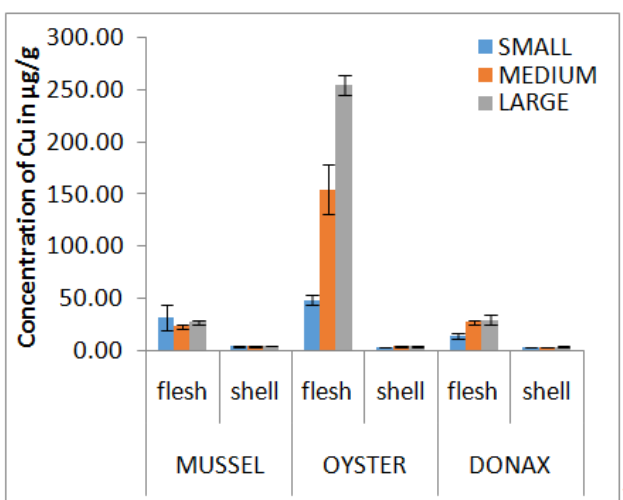

e.

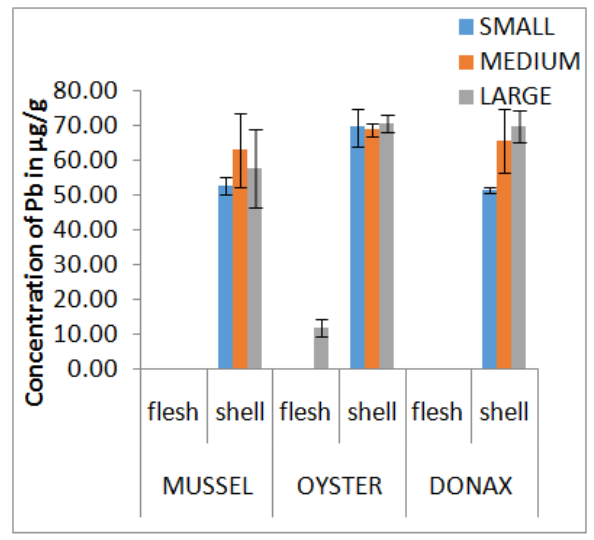

b.

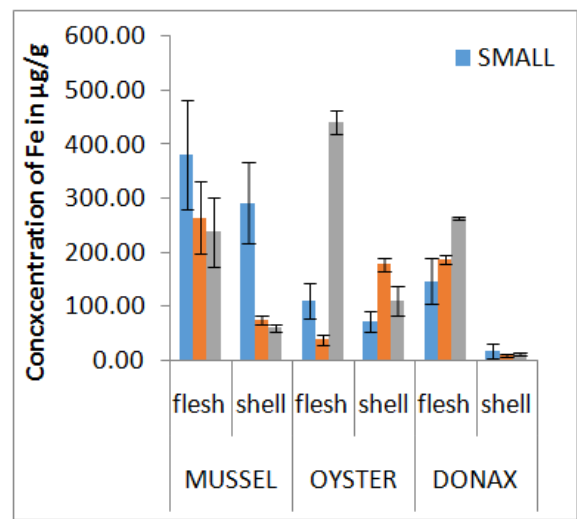

d.

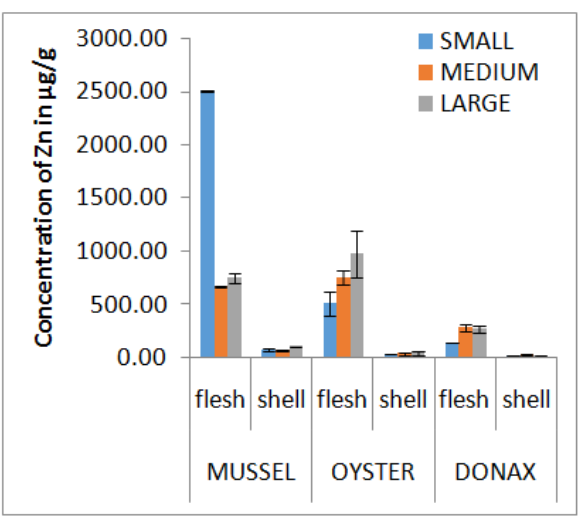

f.

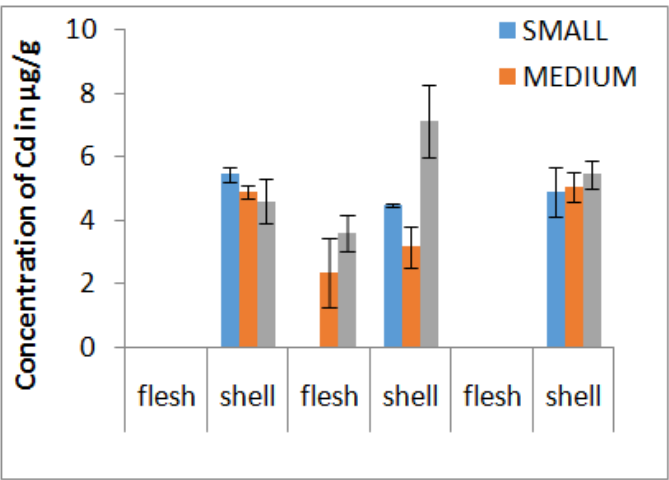

g.

Figure 3: Concentration levels of heavy metals in bivalves 
$\mathrm{Zn}$ and Fe had the highest concentration levels in all bivalves (Fig 3d, f). The concentration levels for $\mathrm{Zn}$ ranged $13.80 \pm 3.23$ in the donax and $2504.92 \pm 6.96$ in mussels between $9.15 \pm 2.57 \mu \mathrm{g} / \mathrm{g}$ to $440.13 \pm 22.39$ $\mu \mathrm{g} / \mathrm{g}$. The major contributors of $\mathrm{Fe}$ and $\mathrm{Zn}$ in the environment are anthropogenic sources such as Municipal waste disposal and discharge from industries [19], [8]. Another source of Fe is from the historical background of the study sites especially Fort Jesus [28]. It was used as a prison and war zone in the $16^{\text {th }}$ century by Portuguese. Debris of metals is evident at the shore. While coast general site, is a docking area for boats and small ships. They are also essential metals needed for the metabolic functions in the marine organisms. Therefore, the bivalves tend to accumulate $\mathrm{Fe}$ and $\mathrm{Zn}$ in high concentration in their bodies. This is in agreement with a study by [19] in mussels and oyster and [5] in mussels that showed high levels of zinc.

The concentration level of $\mathrm{Cu}$ ranged between $2.90 \pm 0.48$ to $254.98 \pm 9.50 \mu \mathrm{g} / \mathrm{g}$ and $\mathrm{Cr}$ ranged between $10.14 \pm 1.10$ to $98.24 \pm 19.73 \mu \mathrm{g} / \mathrm{g}$. the concentration level was found to be high in the flesh samples compared to the shell samples of the bivalves (Fig a, e). These are also essential metals that are needed in high concentration in living organisms that aids in metabolic functions. While $\mathrm{Mn}$ concentration levels ranged between $0.084 \pm 0.004$ to $19.97 \pm 2.70 \mu \mathrm{g} / \mathrm{g}$ were low in the flesh and high in the shells. Sources of these metals could be from industrial activities and sewage disposal at the studied sites [28], [29].

$\mathrm{Pb}$ had concentration levels ranging between $52.59 \pm 2.42$ to $70.35 \pm 2.47 \mu \mathrm{g} / \mathrm{g}$ while $\mathrm{Cd} 3.15 \pm 0.67$ to $13.92 \pm 1.24 \mu \mathrm{g} / \mathrm{g}$ were detected in high concentration in the shells of all organisms but below detection limit in the flesh of all bivalves except in oysters (Fig $3 \mathrm{~g}$ and $\mathrm{b}$ ). The high concentration level of these toxic metals could be attributed to discharge of municipal waste at the shores [28] as well as from the paints or oils from ships especially at Coast General hospital site. These metals are toxic and are not metabolized in the bivalves hence are easily excreted from the flesh. The high concentration levels in the shells could be because of the structural nature of the shells. They are made up of calcium carbonate in form of aragonite and calcite. The aragonite is isostractural to lead carbonate while calcium $(9.7 \mathrm{~nm})$ has similar ionic radii with $\mathrm{Cd}(9.8 \mathrm{~nm})$, therefore the toxic metals have a tendency of replacing the calcium in the shells especially under low $\mathrm{pH}$ [30], [24], [28].

\subsection{Comparison of Heavy Metals Based on the Sizes of Mollusks}

The size of organisms can affect heavy metals bioaccumulation. Increase in weight of an organism can lead to decrease in metal concentration if the growth rate is higher than bioaccumulation. This is due to heavy metal dilution [19].

Table 3: Correlation coefficient between metal concentration in flesh with body weight and length of mollusks

\begin{tabular}{|l|l|l|l|l|l|l|}
\hline \multirow{2}{*}{ Metals } & Mussels & \multicolumn{2}{l|}{ Donax } & Oysters \\
\cline { 2 - 7 } & Weight & Length & Weight & Length & Weight & Length \\
\hline Fe & -0.99 & -0.96 & 0.96 & 0.93 & 0.66 & 0.91 \\
\hline Cd & 0 & 0 & 0 & 0 & 0.95 & 0.72 \\
\hline $\mathbf{Z n}$ & -0.93 & -0.87 & 0.82 & 0.77 & 0.99 & 0.96 \\
\hline $\mathbf{C u}$ & -0.64 & -0.59 & 0.70 & 0.75 & 0.95 & 0.99 \\
\hline $\mathbf{M n}$ & 0 & 0 & 0 & 0 & 0 & 0 \\
\hline $\mathbf{P b}$ & 0 & 0 & 0 & 0 & -0.93 & -0.70 \\
\hline $\mathbf{C r}$ & 0.94 & 0.98 & 0 & 0 & -0.96 & -0.75 \\
\hline
\end{tabular}

There was a strong positive correlation between $\mathrm{Cr}$ concentration and size in mussels (Table 4). While a negative correlation was found between $\mathrm{Zn}$ and Fe concentration and size. This indicated that bioaccumulation of heavy metals in mussels was not dependent on size of the organism.

The relationship between oysters' body weight and metal concentration was strong in all metals except for $\mathrm{Fe}$. A negative correlation was however observed between $\mathrm{Pb}$ and $\mathrm{Cr}$ concentration and size (Table 4). Oysters also had a strong correlation between concentration of metals and length with the strongest relationships in $\mathrm{Fe}, \mathrm{Zn}$ and $\mathrm{Cu}$. This shows that metal concentration is highly affected by size of organism. When the size of the oyster is large the essential minerals $(\mathrm{Fe}, \mathrm{Cu}$ and $\mathrm{Zn}$ ) and accumulated more, while the toxic metals concentration is reduced with size.

In donax, the strongest positive correlation was between iron concentration levels in soft tissues and both the body weight and length followed by $\mathrm{Zn}$ and $\mathrm{Cu}$ (Table 4). This means that accumulation of $\mathrm{Znand} \mathrm{Cu}$ increased with size for donax. Notably, no correlation was observed between Mn and either weight or length in all the bivalves, and similarly $\mathrm{Pb}$ in donax and mussles, and $\mathrm{Cr}$ in chitons and donax (Table 4).

Table 4: Correlations coefficients between metal concentrations in shells with shell length of molluscs

\begin{tabular}{|l|l|l|l|}
\hline Metals & Oysters & Donax & Mussels \\
\hline Fe & 0.10 & -0.88 & -0.92 \\
\hline Cd & 0.83 & 0.95 & -0.99 \\
\hline Zn & -0.99 & 0.41 & 0.83 \\
\hline Cu & 0.64 & 0.52 & 0.83 \\
\hline
\end{tabular}




\begin{tabular}{|l|l|l|l|}
\hline $\mathbf{M n}$ & -0.52 & -0.96 & -0.57 \\
\hline $\mathbf{P b}$ & 0.76 & 0.99 & 0.54 \\
\hline $\mathbf{C r}$ & -0.71 & 0.88 & -0.25 \\
\hline
\end{tabular}

There was a strong positive correlation between length of shell and concentration of cadmium in donax, and oyster, $\mathrm{Zn}$ in mussels and $\mathrm{Pb}$ in oysters and donax shells (Table 4). Donax was the only mollusk with a strong positive correlation between size and concentration of $\mathrm{Cr}$ in shells. This suggests that these metals are accumulated as the size of the organism increases in all mollusks.

Oyster shells had a weak positive correlation with Fe, while all mollusks studied showed a strong negative correlation of $\mathrm{Fe}$ concentration with shell length (Table 4). This suggests that the accumulation of iron in the shells of these organisms is not dependent on increase in age/size of organism making them good candidates for bioaccumulation monitoring for iron.

\subsection{Heavy Metals in Water and Sediment}

The concentration level for water and sediment samples were within acceptable limits set by USEPA [29]. Cd was below detection limit for the sediment samples in both sites, while in water samples, only Coast General Hospital samples were below detection limit. This result is similar to [14] who found Cd in water samples to be below detection limit at Tudor creek. The levels were significantly different $(\mathrm{P}<0.05)$.Cd is a rare metal and its occurrence is majorly due to anthropogenic activities like mining and from industrial waste. $\mathrm{Mn}$ and $\mathrm{Cr}$ were below detection limits in the water samples but detected in sediment samples (Table 1). These metals occur naturally in the environment however they are efficiently removed during industrial activities before industrial waste is released to the environment. The concentration levels were however not significantly different for the two sites $(\mathrm{P}>0.05)$.

Table 5: Metal concentration levels on sediments and water samples at different sampling sites

\begin{tabular}{|l|l|l|l|l|}
\hline \multicolumn{2}{|l|}{ Sediments samples(concentration in $\boldsymbol{\mu g} / \mathbf{g}$ dry wt) } & \multicolumn{2}{l|}{ Water samples (concentration in mg/L) } \\
\hline Metals & Fort Jesus & Coast General Hospital & Fort Jesus & Coast General Hospital \\
\hline $\mathbf{P b}$ & $38.25 \pm 2.82^{*}$ & $12.75 \pm 1.50^{*}$ & $\mathrm{Nd}$ & $0.012 \pm 0.002$ \\
\hline $\mathbf{M n}$ & $7.69 \pm 4.41$ & $10.95 \pm 0.59$ & $\mathrm{Nd}$ & $\mathrm{Nd}$ \\
\hline $\mathbf{C r}$ & $4.61 \pm 1.34$ & $1.65 . \pm 0.32$ & $\mathrm{Nd}$ & $\mathrm{Nd}$ \\
\hline $\mathbf{F e}$ & $1174.50 \pm 9.52^{*}$ & $460.71 \pm 17.73^{*}$ & $25.0 \pm 5.66$ & $36.0 \pm 7.07$ \\
\hline $\mathbf{C d}$ & $\mathrm{Nd}$ & $\mathrm{Nd}$ & $0.0043 \pm 0.0003^{*}$ & $\mathrm{Nd}^{*}$ \\
\hline $\mathbf{Z n}$ & $34.19 \pm 3.13$ & $28.79 \pm 5.43$ & $0.007 \pm 0.004$ & $\mathrm{Nd}$ \\
\hline $\mathbf{C u}$ & $1.42 \pm 0.14$ & $4.61 \pm 1.34$ & $\mathrm{Nd}$ & $0.0043 \pm 0.00071$ \\
\hline
\end{tabular}

The asterisks * indicate significant difference at $95 \%$ confidence level (P> 0.005 one-wayanova).

Fe had the highest concentration levels in both the sediment and water samples compared to the other metals. The levels of Fe in sediment from the two sites were significantly different $(\mathrm{P}<0.05)$. The levels of $\mathrm{Fe}$ in these sites were lower compared to a study done by [12] at Portrieze creek $(6,562-32,260 \mu \mathrm{g} / \mathrm{g})$. The high levels of Fe could be due to natural as well as anthropogenic activities like sewage waste disposal at the shore.

Lead concentration in water samples was below detection limit in FJ but had a concentration of $0.012 \pm 0.002 \mathrm{mg} / \mathrm{L}$ in CG, while in sediment samples, the concentration levels were $38.25 \pm 2.82 \mu \mathrm{g} / \mathrm{g}$ at Fort Jesus and $12.75 \pm 1.50 \mu \mathrm{g} / \mathrm{g}$ at $\mathrm{CG}$ (Fig 1$)$ the concentration levels were significantly different $(\mathrm{P}<0.05)$. This data is in agreement with previous studies by [14], reported lead concentration ranging from nd to $0.6 \mathrm{mg} / \mathrm{L}$ in water samples, and 0.2 to $58.0 \mu \mathrm{g} / \mathrm{g}$ in sediment samples in Mombasa.

Concentrations of zinc were recorded at $28.79 \pm 5.43 \mu \mathrm{g} / \mathrm{g}$ to $34.19 \pm 3.13 \mu \mathrm{g} / \mathrm{g}$ in sediment samples at $\mathrm{CG}$ and FJ respectively, and were higher at FJ. In water samples, zinc was below detection limit in CG but had a concentration of $0.007 \pm 0.004 \mathrm{mg} / \mathrm{L}$ in FJ sampling site (Figure 1). While the concentration of copper in water samples in FJ was below detection limit $0.0043 \pm 0.00071 \mathrm{mg} / \mathrm{L}$ in CG, while sediment ranged from $1.42 \pm 0.14$ $\mu \mathrm{g} / \mathrm{g}$ at $\mathrm{FJ}$ and $4.61 \pm 1.34 \mu \mathrm{g} / \mathrm{g}$ at CG (Fig 1). The concentration levels of both $\mathrm{Zn}$ and $\mathrm{Cu}$ for the two sites were not significantly different.

\subsection{Biota Sediment Accumulation Factor (BSAF)}

Biota-Sediment accumulation factor is a ratio that measures efficiency of metal bioaccumulation in the flesh of the bivalves and the sediment. It is calculated as a ratio between concentrations of heavy metals in an organism CB, to the concentration of heavy metals in sediment CS. It is expressed as: $\mathbf{B S A F}=\mathbf{C B} / \mathbf{C S}$ [26].

The BSAF was determined for marine donax samples only because they were the only bivalve in this study that live in sediment. The BSAF was in this order for all metals $\mathrm{Zn}>\mathrm{Cr}>\mathrm{Cu}>\mathrm{Pb}>\mathrm{Fe}>\mathrm{Mn}$ (Table 12). 
Table 6: Bio-Sediment Accumulation Factor (BSAF) for donax from sandy shores of Coast General Hospital

\begin{tabular}{|l|l|l|l|l|l|l|l|}
\hline Size & Pb & Mn & Cr & Fe & Cd & Zn & Cu \\
\hline Small & - & 0.01 & 10.96 & 0.32 & - & 4.74 & 5.93 \\
\hline Medium & - & 0.01 & 5.4 & 0.47 & - & 9.84 & 5.79 \\
\hline Large & - & 0.01 & 5.4 & 0.51 & - & 9.22 & 6.3 \\
\hline
\end{tabular}

Zn had highest BSAF but its concentration in the sediment was lower than Fe. The concentration levels of $\mathrm{Zn}, \mathrm{Cu}$ and $\mathrm{Cr}$ in the flesh was high this means that there is high accumulation of $\mathrm{Zn}$ by the organisms. The bio-sediment accumulation factor for $\mathrm{Cr}$ in small sized donax was the highest while for $\mathrm{Zn}$ it was in the medium sized donax (Fig 4).

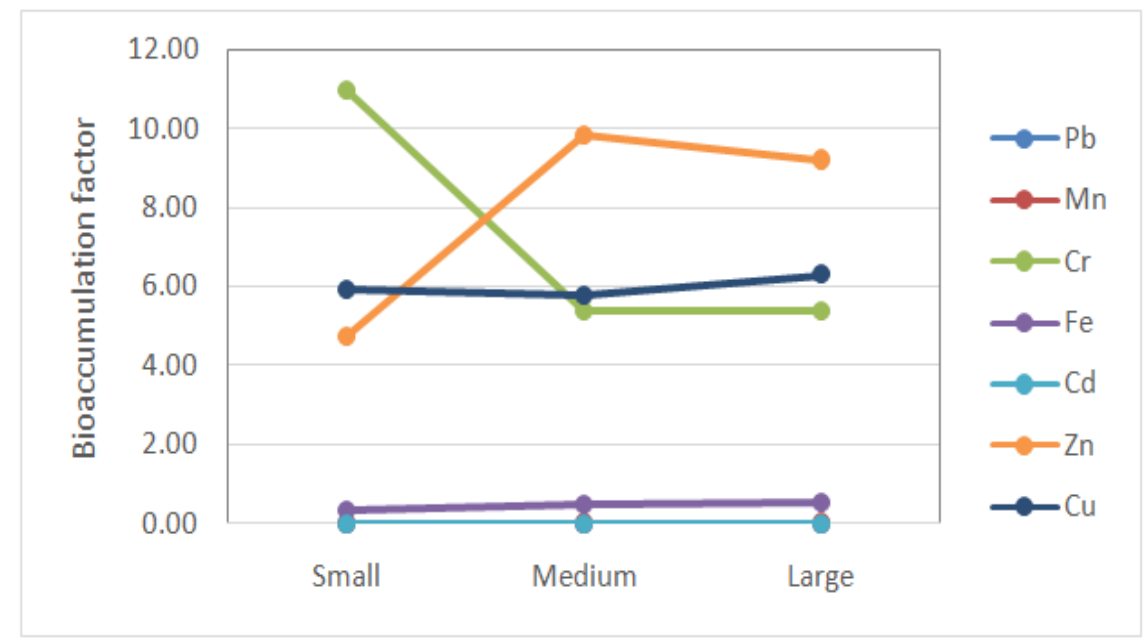

Figure 4: Biota sediment accumulation factor for donax

Fe and Mn concentration levels were found to be high in the sediment as compared to the organism. This means that the sediment have a greater capacity of accumulating these metals more than the donax from this study area.

\subsection{Bioaccumulation factor}

Bioconcentraion involves uptake of chemical pollutants by absorption from water that will result to the concentration of in the organisms being higher than in water [31]. This is a ratio of the chemical concentration in an organisms $\mathrm{CB}$, to the total dissolved chemical concentration in the water CWT and it is expressed as: $\mathbf{B C F}=$ $\mathrm{CB} / \mathrm{CWT}$

The bioaccumulation or bioconcentration factors followed the following trend $\mathrm{Zn}>\mathrm{Cu}>\mathrm{Cd}>\mathrm{Fe}$ (Table 7). Although $\mathrm{Fe}$ was found to have high concentrations in the tissues of the bivalves its bioaccumulation factor was low because its concentration in the water samples was also high. The bioaccumulation factors which were greater than 1000 for the bivalves could indicate either significant and slow accumulation of pollutant or the pollutant is accumulated in food chain.

The bioaccumulation factor for $\mathrm{Cu}$ and $\mathrm{Cd}$ was high in the bivalves, while concentration of $\mathrm{Cu}$ and $\mathrm{Cd}$ was low in the water samples compared to the bivalves (Table 7). This means that the organisms can bioaccummulate high concentration of these metals compared to water.

Table 7: Bioaccumulation Factor

\begin{tabular}{|c|c|c|c|c|c|c|c|c|c|}
\hline \multirow[t]{3}{*}{ Metal } & \multicolumn{9}{|c|}{ Bioaccumulation factor } \\
\hline & \multicolumn{3}{|c|}{ Donax } & \multicolumn{3}{|l|}{ Oyster } & \multicolumn{3}{|l|}{ Mussels } \\
\hline & $\mathbf{S}$ & $\mathbf{M}$ & $\mathbf{L}$ & S & $\mathbf{M}$ & $\mathbf{L}$ & $\mathbf{S}$ & $\mathbf{M}$ & $\mathbf{L}$ \\
\hline $\mathbf{F e}$ & 4.06 & 5.99 & 6.51 & 4.42 & 1.56 & 17.61 & 15.22 & 10.55 & 9.49 \\
\hline Cd & - & - & - & - & 798.41 & 831.49 & - & - & - \\
\hline $\mathbf{Z n}$ & - & - & - & 72316.98 & 107462.68 & 138851.38 & 357846.32 & 95128.70 & 106563.70 \\
\hline $\mathrm{Cu}$ & 6363.53 & 6209.26 & 6813.16 & - & - & - & - & - & - \\
\hline
\end{tabular}

The bioaccumulation factor for zinc was the highest for all organisms except donax. The small sized mussels had the highest bioaccumulation factor followed by large sized oyster (Fig5). 


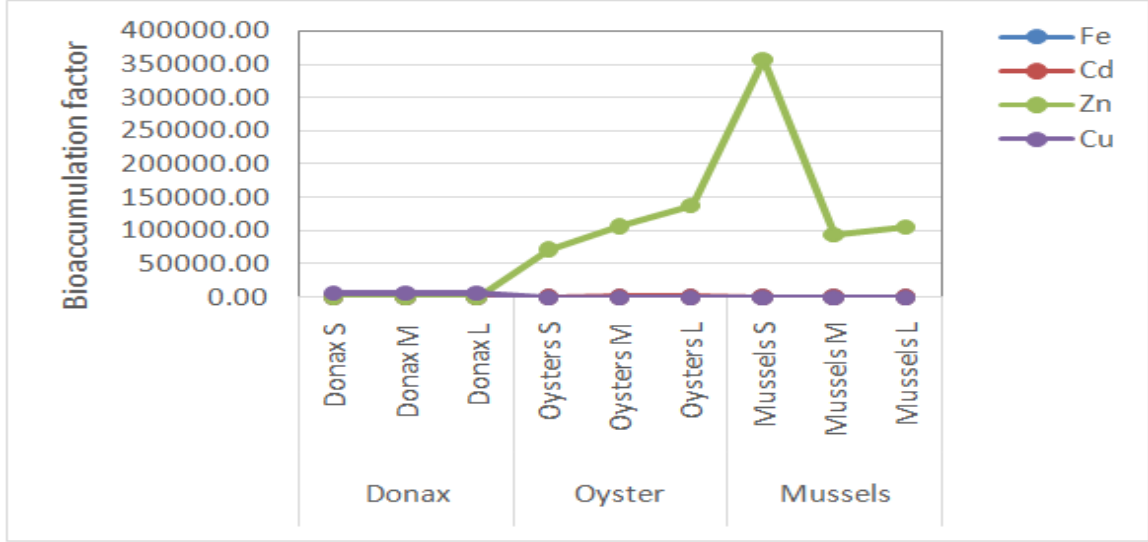

Figure 5: Bioaccumulation factor for bivalves

Zinc is an essential metal that occurs in high quantities in the mussels. This high bioaccumulation factor shows that these organisms are better accumulators of the zinc metal than water.

\subsection{Health Risks of Heavy Metals in the Bivalves}

The bivalves in this study are commonly used as food amongst the locals at the Kenyan coast, however, if consumed could pose a health risk to humans. To determine the health risk the levels of heavy metals in this study was compared with the maximum permissible limits as set by international organizations. It was noted in this study that, the concentration levels of $\mathrm{Zn}$ and $\mathrm{Cu}$ in the flesh of the bivalve species analyzed were above acceptable limits set by Food and Agriculture Organization (FAO) and World food organization (WHO) (Table 6). The highest concentration level of $\mathrm{Zn}$ in the flesh of mussels was $2504.92 \pm 6.96 \mu \mathrm{g} / \mathrm{g}$ and for $\mathrm{Cu}$ in the flesh of oysters being $254.98 \pm 9.50 \mu \mathrm{g} / \mathrm{g}$.

While $\mathrm{Pb}$ and $\mathrm{Cd}$ which are highly toxic metals were found to be above acceptable limits in oysters flesh samples. The highest concentration levels of $\mathrm{Pb}$ and $\mathrm{Cd}$ in oysters were $11.77 \pm 2.38 \mu \mathrm{g} / \mathrm{g}$ and $3.57 \pm 0.57$ $\mu \mathrm{g} / \mathrm{g}$.

Table 8: Standards for heavy metals in shell fish (Source: [32])

\begin{tabular}{|l|l|l|l|l|l|l|l|}
\hline & Pb & Fe & Cu & Mn & Zn & Cr & Cd \\
\hline WHO (1989) & 2.0 & 100 & 30 & 1 & 100 & 50 & 1 \\
\hline FAO(1983) & $0.5-6$ & - & $10-100$ & - & $30-100$ & 1 & $0.05-5.5$ \\
\hline
\end{tabular}

\subsection{Heavy Metals in Rock Samples}

Slopes of rocky cliffs at the Kenyan coast begin at eulittoral zone. The sessile organisms like Mytilus edulis or the Saccostrea cucullata are found in the eulittoral zone [33]. Bivalves tend to vary in size depending on their position at the shore,the difference in size could be due to the difference in the duration and frequency of feeding period when exposed to water [34].

The concentration level of heavy metals in the rock samples also varied with the level at the shore (Fig6). $\mathrm{Mn}, \mathrm{Cr}$ and $\mathrm{Zn}$ were highest in the lower rocks at $23.67 \pm 0.77 \mu \mathrm{g} / \mathrm{g}, 4.10 \pm 0.33 \mu \mathrm{g} / \mathrm{g}$ and $4.10 \pm 0.27 \mu \mathrm{g} / \mathrm{g}$ respectively. While $\mathrm{Pb}$ and $\mathrm{Cd}$ were below detection limit in the rock samples.

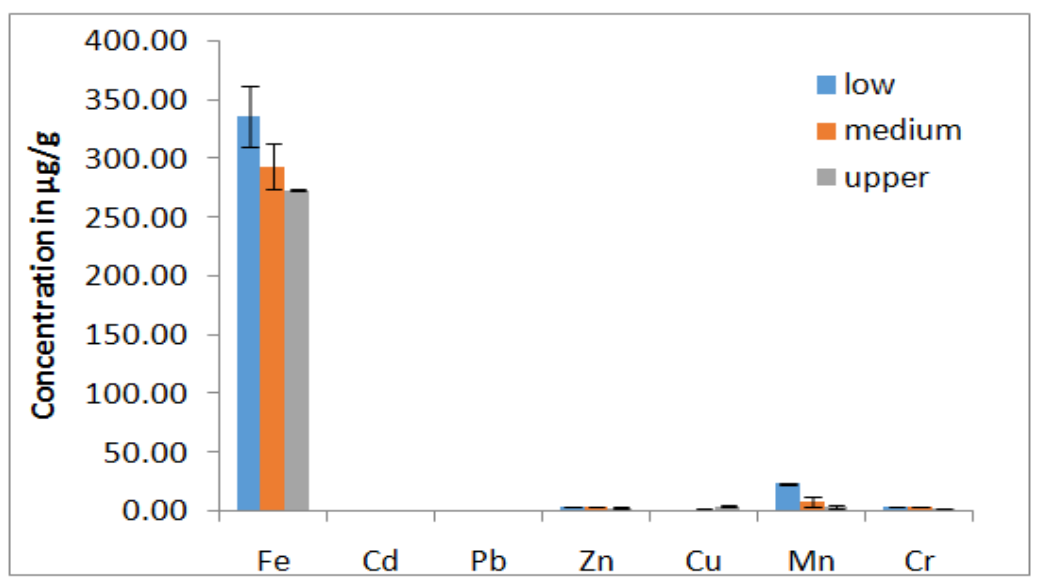

Figure 6: Concentration of metals in rock samples 
Iron and copper were highest in the lower rocks at $336.64 \pm 25.79 \mu \mathrm{g} / \mathrm{g}$ and $4.36 \pm 2.64 \mu \mathrm{g} / \mathrm{g}$ respectively (Fig6). These findings suggest that the lower shoreline rocks are more exposed to these heavy metals than the other rocks. Therefore the organisms at this shore levels could be more exposed to the metals. However, most of the concentration levels for most heavy metals in the rock samples were lower than those found in the organisms except for $\mathrm{Cr}, \mathrm{Mn}$ and Fe. These findings suggest that the bioaccumulated metals in bivalves were most likely as a result of anthropogenic influences and less of natural occurrence. Metals in rocks are less likely to be dangerous unless if dissolved in water through weathering, volcanic activities or leaching [35].

The concentration levels of heavy metals are lower in water and rock samples compared to the one found in sediment samples. This could be because the heavy metal can be sorbed on the sediment, precipitated as oxides, phosphates, sulphides or sulphates or the metallic species adsorbs to organic matter found in the sediment [35]. However, the high levels of metals in sediment depend on sources of the pollutants.

\section{Conclusions}

This study has showed that the concentration levels of the heavy metals in the marine bivalves are high. Bioaccumulation in the bivalve species followed the following trend oysters $>$ mussels $>$ donax. This shows that oysters are the best bioaccumulators compared to the other bivalves species based on the metal bioavailability in the oysters.

Mussels were found to be good bioaccumulators of $\mathrm{Cr}$ and $\mathrm{Zn}$, were good bioaccumulators of $\mathrm{Mn}$ and $\mathrm{Fe}$ and oysters were good bioaccumulators of $\mathrm{Cu}, \mathrm{Pb}$ and $\mathrm{Cd}$. Heavy metals bioaccumulation in bivalves is dependent on the body part. The concentration levels were higher in the flesh samples for $\mathrm{Fe}, \mathrm{Zn}$, and $\mathrm{Cu}$ while $\mathrm{Pb}, \mathrm{Mn}, \mathrm{Cd}$, and $\mathrm{Cr}$ were higher in the shell samples.

These bivalves could pose a health risks if consumed because the levels of heavy metals concentration were high compared to WHO and FAO. The bivalves were also found to be better accumulators of heavy metals compared to water and sediment.

\section{Acknowledgment}

We would like to acknowledge National Council for Science and Technology (NACOSTI) for the financial support providedthrough the postgraduate research Grant. We also acknowledge Kenya Marine and Fisheries Research Institute (KEMFRI) library for the reading materials. We thank the staff at Pwani University and Mr. Gonda from KEMFRI for their assistance and support.

\section{References}

[1]. International Union of Pure and Applied Chemistry, 1993, Glossary for chemists of terms used in toxicology: Pure and Applied Chemistry, 65(9):2003-2122.

[2]. Baby j., Raj J. S., Biby E. T., Sankarganesh P., Jeevitha M. V., Ajisha S. U. and Rajan S. S., (2010) Toxic Effects of Heavy Metals on Aquatic Environment. International Journal of Biological and Chemical Science 4(4): 939-952

[3]. Duffus J. H., (2002) "Heavy Metals" - A meaningless term. Pure and Applied Chemistry, 74: 793-807.

[4]. UNEP/GPA (2006), The State of the Marine Environment: Trends and Processes. UNEP/GPA,The Hague.

[5]. Burger J. and Gochfeld M., (2006) Locational Differences in Heavy Metals and Metalloids in Pacific Blue Mussels Mytilus [edulis] trossulus from Adak Island in the Aleutian Chain, Alaska. Science of the Total Environment, 368: 937 - 950.

[6]. Jitar O., Teodosiu C., Nicoara M., Gabriel Plavan G., (2013) Study of Heavy Metal Pollution and Bioaccumulation in the Black Sea Living Environment. Environmental Engineering and Management Journal, 12(2): 271-276.

[7]. Hamdani A. and Soltani-Mazouni N., (2011) Changes in Biochemical Composition of the Gonads of Donaxtrunculus L. (Mollusca, Bivalvia) from the Gulf of Annaba (Algeria) in Relation to Reproductive Events and Pollution. Jordan Journal of Biological Sciences, 4(3): 149-156.

[8]. Okuku E. O., Ohowa B., Mwangi S.N., Munga D., Kiteresi L., Wanjeri V. O., Okumu S. and Kilonzo J., (2011) Sewage Pollution in the Coastal Waters of Mombasa City, Kenya: A Norm Rather than an Exception. International Journal of Environmental Resources, 5(4): 865-874.

[9]. Matoka C. M., Omolo S.O. and Odalo J. O., (2014) Heavy Metal Bioaccumulation as Indicators of Environmental Pollution and Health Risks. Journal of Environmental Science, Toxicology and Food Technology, 8(2):24-31.

[10]. Kenya Bureau of National

(2009) www.knsb.or.ke/index.php?option=com_content\&view=article\&i=176\&Itemid=645

[11]. Mohamed O. S., Neukermans G, Kairo J. M., Dahdouh-Guebas F. and Koedam N., (2009) Mangrove Forests in a Peri-urban Setting: the Case of Mombasa (Kenya). Wetlands Ecology and Management, 17:243-255.

[12]. Kamau J. N. (2002) Heavy Metal Distribution and Enrichment at Port-Reitz Creek, Mombasa. Western Indian Ocean Journal of Marine Science 1: (1)65-70.

[13]. Ochieng E. Z., Lalah J. O., Wandiga S. O. (2009) Anthropogenic Sources of Heavy Metals in the Indian Ocean Coast of Kenya. Bulletin of Environmental Contamination and Toxicology, 83(4):600-7

[14]. Mwashote B. M., (2003) Levels of Cadmium and Lead in Water, Sediments and Selected Fish Species in Mombasa, Kenya. Western Indian Ocean Journal of Marine Science, 2(1): 25-34

[15]. Muohi W. (2002) Occurrence of Heavy Metals in Sediments, Fish and Oysters from Mtwapa, Port Reitz, Makupa and Shirazi Creeks along the Kenyan Coast. University of Nairobi.

[16]. Gofas, S. (2015). Mytilus edulis Linnaeus, 1758. In: Mollusca Base (2015). Accessed through: Odido, M.; Appeltans, W.; BelHassen, M.; Mussai, P.; Nsiangango, S.E.; Vandepitte, L.; Wambiji, N.; Zamouri, N. Jiddou, A.M. (Eds) (2015) African Register of Marine Species at http://www.marinespecies.org/afremas/aphia.php?p=taxdetails\&id=140480 on 2015-11-21 
[17]. Gofas, S. (2015). Saccostrea cucullata (Born, 1778). In: MolluscaBase (2015). Accessed through: Odido, M.; Appeltans, W.; BelHassen, M.; Mussai, P.; Nsiangango, S.E.; Vandepitte, L.; Wambiji, N.; Zamouri, N. Jiddou, A.M. (Eds) (2015) African Register of Marine Species at http://www.marinespecies.org/afremas/aphia.php?p=taxdetails\&id=181316 on 2015-11-21

[18]. National Oceanic and Atmospheric Administration (NOAA), (1993) Sampling and Analytical Methods of the National Status and Trends Program National Benthic Surveillance and Mussel Watch Projects 1984-1992, Overview and Summary of Methods. NOAA Technical Memorandum NOS ORCA 71.Volume I.

[19]. Otchere F.A., (2003). Heavy Metals Concentrations and Burden in the Bivalves (Anadara (Senilia) senilis, Crassostreatulipa and Pernaperna) from Lagoons in Ghana: Model to Describe Mechanism of Accumulation/Excretion. African Journal of Biotechnology, 2(9): 280-287.

[20]. Amisah S., Adjei-Boateng D., Obirikorang K. A. and Quagrainie K. K. (2009) Effects of Clam Size on Heavy Metal Accumulation in Whole Soft Tissues of Galatea paradoxa(Born, 1778) from the Volta Estuary, Ghana. International Journal of Fisheries and Aquaculture, 1(2):014-021.

[21]. Sarkar S. K., Cabral H., Chatterjee M., Cardoso I., Bhattacharya A. K., Satpathy K. K. and Alam M.A, (2008) Biomonitoring of Heavy Metals Using the Bivalve Molluscs in Sunderban Mangrove Wetland, Northeast Coast of Bay of Bengal (India): Possible Risks to Human Health. Clean, 36(2):187-194.

[22]. Prakash N. T., Naidu T. S. and Rao K. S. J., (1994) Metal content in selected tissues and shells of Pernaviridis(L) from east coast of India. Chemistry and Ecology, 9: 1-6.

[23]. Hauxin W., Lejun Z. and Presley B. J., (2000) Bioaccumulation of Heavy Metals in Oyster (CrassostreaVirgica) Tissues and Shells. Environmental Geology, 39(1): 1216-1226.

[24]. Hashem A. M., (2005) Distribution and Relationships of Heavy Metals in Giant Clam (Tridacna maxima) and Associated Sediments from Different Sites in the Egyptian Red Sea Coast. Egyptian Journal of Aquatic Research, 31(2): 45-59

[25]. Linga R. C. H., Narasimhulu K. V., Gopal N.O., Rao J. L. and Reddy B. C. V., (2003). Structural Studies of marine exoskeletons: Redox mechanisms Observed in the $\mathrm{Cu}$-supported $\mathrm{CaCO}_{3}$ Surfaces Studied by EPR. Spectrochemical. Acta. Part A, 59: $2955-2965$.

[26]. Adu O. K., (2010) An Assessment of Heavy Metals Contamination of Sediments and Tissues of the clam galateaparadoxa (born 1778 ) in the Volta Estuary, Ghana. MPHIL Thesis, Fisheries and Water Shed Management.

[27]. Government of Kenya, (2009) State of the Coast Report, Towards Integrated Management of Coastal and Marine Resources in Kenya. National Environmental Management Authority, (NEMA) Nairobi 88pp.

[28]. Swaleh M. M. Ruwa R., Wainaina M. N., Loice M. Ojwang' ${ }^{1}$ L. M., Shikuku L. S.and Maghanga J. K. (2016) Heavy Metals Bioaccumulation Assessment in Acanthopleuragemmatafrom Fort Jesus Mombasa, Journal of Environmental Science Toxicology and Food Technology. 10(7): 39-45

[29]. Prakash N., Rao J. K. S., (1993) Relationship between the metal content in bivalve shell and physical parameters. Fresenius Environmental Bulletin 2(9):509-513.

[30]. Mwatsahu S., (2013) Is an Assessment of Heavy Metals in Water, Sediments, and Fauna of Selected Areas along the Kenyan Coastline. A thesis submitted for Msc. Science in Applied Analytical Chemistry in the School of Pure and Applied Science of Kenyatta University.

[31]. Yarsan E., Yipel M., (2013) The Important Terms of Marine Pollution "Biomarkers and Biomonitoring, Bioaccumulation, Bioconcentration, Biomagnification”. Journal of Molecular Biomarkers \& Diagnosis S1: 003. doi:10.4172/2155-9929.S1-003.

[32]. Mokhtar M., Aris Z. A., Munusamy V. (2009) Assessment Level of Heavy Metals in Penaeus Monodon and OreochromisSpp in Selected Aquaculture Ponds of High Densities Development Area. European Journal of Scientific Research 30(3): 348-360

[33]. Ruwa R. K., (1984)Non-encrusting Macroalgal Zonation on Rocky Cliffs Around Mombasa, Kenya Journal of Sciences (B) (1987) 8 (1-2): 77-96

[34]. Ruwa R. K., (1987)Invertebrate faunal zonation. 00 rocky shores around Mombasa, Kenya,Kenya Journal of Science and Technology Series B (1984) 5: 49 -65.

[35]. Abuagla Y. (2013). Marine Algae as Biomonitors for Heavy Metals Pollution at the Red Sea Coast:A review Red Sea University Journal. Refereed scientific biannual Journal Vol.(3)

[36]. Förstner U. and Wittmann G. T. W., (2012) Metal Pollution in the Aquatic Environment. Springer Science \& Business Media, second edition Science - P 1-25. 